\title{
IDENTIFIKASI BIDANG GELINCIR PADA DAERAH RAWAN LONGSOR DESA SRIMARTANI, YOGYAKARTA
}

\author{
Muhammad Faizal Zakaria ${ }^{1}$, Siti Masyithoh Maisarah ${ }^{2}$ \\ ${ }^{1}$ Universitas Pembangunan Nasional "Veteran" Yogyakarta \\ ${ }^{2}$ Universitas Islam Negeri Sunan Kalijaga Yogyakarta \\ Corresponding author: mfaizal@upnyk.ac.id \\ Manuscript received: July 3, 2019; revised: August 21, 2019; \\ Approved: August 23, 2019; available online: November 11, 2019
}

\begin{abstract}
Abstrak-Tanah longsor merupakan salah satu bencana yang sering muncul pada Desa Srimartani, Kecamatan Piyungan, Yogyakarta. Penyebab tanah longsor yang paling besar adalah kemiringan lereng pada suatu area serta keberadaan bidang gelincir pada lereng tersebut. Penelitian ini bertujuan untuk mengidentifikasi bidang gelincir pada lereng di Desa Srimartani. Penelitian ini dilakukan dengan menggunakan metode geolistrik wenner dengan konfigurasi a:10 m dan n:6 sebanyak 6 lintasan yang diambil pada lereng-lereng di Desa Srimartani. Pengolahan data dilakukan dengan menggunakan software Res2Dinv dan hasilnya berupa penampang 2D resistivitas. Hasil dari interpretasi ke enam lintasan tersebut menunjukkan keberadaan bidang gelincir yang ditandai dengan kontras resistivitas rendah pada bagian bawah dan resistivitas yang lebih tinggi dekat permukaan. Resistivitas rendah $(<10$ $\Omega \mathrm{m})$ diidentifikasi sebagai batuan lempung dan resistivitas tinggi $(>10 \Omega \mathrm{m}$ ) diatasnya diidentifikas sebagai soil permukaan.
\end{abstract}

\begin{abstract}
Landslides are one of the disasters that often occur in Srimartani Village, Piyungan District, Yogyakarta. The biggest cause of landslides is the steep slope and the existence of a sliding plane on the slope. This study aims to identify the sliding plane on the slopes in Srimartani Village. This research was conducted using geoelectric method Wenner configuration with a: $10 \mathrm{~m}$ and $\mathrm{n}$ : 6 . The data acquisition was taken in 6 lines. Data processing was done using Res2Dinv software and the result is a $2 \mathrm{D}$ true resistivity cross section. The results of the interpretation of the six lines indicate the existence of a sliding plane which is characterized by low resistivity contrast at the bottom and higher resistivity near the surface. Low resistivity $(<10 \Omega \mathrm{m})$ is identified as clay rock and high resistivity $(>10 \Omega \mathrm{m})$ above is identified as surface soil.
\end{abstract}

Keywords: Geolistrik, Srimartani, longsor, bidang gelincir

How to cite this article:

Zakaria, M.F., dan Maisarah, S.M., 2019, Identifikasi Bidang Gelincir Pada Daerah Rawan Longsor Desa

Srimartani, Yogyakarta, Jurnal Geofisika Eksplorasi, 5 (3) p.214-222. doi: 10.23960/jge.v5i3.36 


\section{PENDAHULUAN}

Tanah longsor di Provinsi Daerah Istimewa Yogyakarta masih menjadi salah satu bahaya bencana alam yang memberikan ancaman bagi masyarakat. Tercatat data BPBD Kabupaten Bantul tahun 2015 (BPBD Bantul. 2015), tanah longsor yang terjadi 50\% adalah akibat dari curah hujan tinggi. Wilayah Kabupaten Bantul yang rawan terhadap longsor terdapat pada 6 kecamatan, 15 desa yang dihuni sejumlah 7000 penduduk. Wilayah yang terdampak rawan longsor salah satunya adalah Desa Srimartani. Bulan November 2017 lalu, merupakan musim penghujan. Media massa mempublikasikan terjadinya tanah longsor dan banjir yang melanda Kabupaten Bantul. Desa Srimartani mengalami bencana tanah longsor akibat curah hujan tinggi, (news.detik.com)

Desa Srimartani menjadi salah satu lokasi yang perlu dilakukan penelitian mengenai tanah longsor. Desa Srimartani dipilih sebagai lokasi penelitian selain karena alasan-alasan yang telah dipaparkan menggunakan data adalah karena secara geografis Desa Srimartani didominasi oleh lereng-lereng yang diduga berpotensi longsor. Penelitian mengenai tanah longsor ini dilakukan menggunakan pendekatan ilmu geofisika. Metode geolistrik resistivitas merupakan salah satu metode geofisika yang menggunakan prinsip Hukum Ohm. Parameter yang diperoleh dari metode ini adalah nilai resistivitas (tahanan jenis) lapisan bawah permukaan tanah. Penerapan metode geolistrik dilakukan dengan beberapa pilihan konfigurasi, pada penelitian ini digunakan konfigurasi Wenner. Konfigurasi Wenner memperoleh data secara lateral, sehingga lapisan bawah permukaan dapat dianalisis lebih tepat.

Penerapan metode geolistrik konfigurasi Wenner ini memenuhi kebutuhan penelitian untuk mengkaji adanya bidang gelincir pada lapisan bawah permukaan tanah (Darsono 2012, Yatini,
2018). Metode Geolistrik juga merupakan metode yang tepat dalam mengidentifikasi retakan-retakan sebagai sumber longsor di bawah permukaan (Agustin, 2017). Bidang gelincir merupakan perlapisan antara lapisan batuan yang bersifat mudah menyerap air dengan lapisan batuan yang sedikit menyerap air (Varnes, 1978). Bidang gelincir dalam penelitian ini menjadi faktor penting keberadaannya untuk diidentifikasi menjadi penyebab terjadinya tanah longsor atau tidak. Demikian perlunya dilakukan penelitian ini untuk mengidentifikasi daerah rawan tanah longsor melalui analisa bidang gelincir yang diperoleh.

\section{METODE PENELITIAN}

Penelitian ini digunakan metode geolistrik konfigurasi Wenner untuk mendapatkan nilai resistivitas lapisan bawah permukaan tanah. alat yang digunakan yaitu Resistivitymeter (Syscal Jr) beserta peralatan yang mendukung lainnya (Gambar 1).

Konfigurasi Wenner dalam pengambilan data menggunakan 4 elektroda dengan 2 elektroda sebagai penginjeksi arus dan 2 elektroda lainnya sebagai potensial (Loke, 1990). Posisi elektroda dan konfiguasi perpindahan elektroda ditunjukkan pada Gambar 2.

Pengambilan data dimulai dengan persiapan alat dan bahan yang dibutuhkan. Tahapan selanjutnya adalah akuisisi data dengan menggunakan alat Syscal Jr. Data lapangan yang didapatkan adalah data $\Delta \mathrm{V}$ (beda potensial) dan I (Arus). QC data dilakukan dengan mengulangi pengukuran per titik selama beberapa kali sampai didapatkan hasil yang stabil. Dari data lapangan dihitung $\mathrm{R}$ (Hambatan) dan $\rho$ (resistivitas) untuk diolah menggunakan software Res2dInv. Tahapan dalam pengambilan data dapat dilihat pada diagram alir yang ditunjukkan pada Gambar 3. 


\section{HASIL DAN PEMBAHASAN}

Penelitian pada lintasan terdiri dari panjang lintasan $200 \mathrm{~m}$, spasi antar elektroda $10 \mathrm{~m}$, serta pengukuran dilakukan hingga $\mathrm{n}$ (level) 6. Penentuan lokasi lintasan penelitian ditinjau dari peta kemiringan, sekaligus persebaran pemukiman penduduk sekitar. Daerah penelitian terdapat satu titik longsor yang telah terjadi pada tahun 2017 di koordinat (445040; 9133662; 454). Titik longsor berdasarkan peta kemiringan terletak pada kemiringan $15^{\circ}$ sampai $35^{\circ}$ dengan keterangan warna merah muda ditunjukkan lokasi longsoran pada titik biru tampak pada gambar 4. Penentuan lokasi kemiringan pada lokasi penelitian dilakukan dengan menggunakan data DEM (Digital Elevation Model). Daerah bekas longsor tidak dilakukan pengambilan data tepat di titik tersebut. Pengambilan data dilakukan di bawah area bekas longsoran, yaitu pada lintasan empat. Lokasi daerah penelitian seperti tampak pada gambar 4 .

Beberapa hasil pengambilan data geolistrik diperoleh lintasan penelitian sebagai berikut:

\section{a. Lintasan Satu}

Hasil dari pengukuran lintasan satu setelah diolah menggunakan Res2dinv, diperoleh hasil data seperti pada gambar 5 . Lintasan satu memiliki nilai resistivitas mulai dari 3,15 s.d. $28 \Omega \mathrm{m}$. Analisis pada lintasan satu untuk nilai resistivitas 3 s.d. 10,4 $\Omega \mathrm{m}$ sebagai lempung. Tanah permukaan memiliki nilai resistivitas 3,15 s.d. $28 \Omega \mathrm{m}$. Hasil klasifikasi lapisan bawah permukaan dapat diidentifikasi tiga jenis lapisan batuan pada lintasan satu dari Gambar 5, sehingga dihasilkan perlapisan bawah permukaan tersusun atas tiga batuan pada Gambar 6.

Hasil analisa dari lintasan ini yaitu, pada lintasan ini terdapat bidang gelincir yang cenderung searah dengan kemiringan lereng serta diduga tanah permukaan cukup tebal. Apabila terjadi peningkatan curah hujan tinggi, daerah ini dapat terjadi longsor. Kondisi lintasan satu ini berada pada kemiringan $8^{\circ}$ s.d. $16^{\circ}$ dan berada di daerah pemukiman penduduk. Demikian pada lintasan satu dapat dikatakan memiliki potensi rawan longsor.

\section{b. Lintasan Dua}

Berdasarkan Gambar 7 lintasan dua memiliki nilai resistivitas mulai dari 1,47 s.d. $55 \Omega \mathrm{m}$. Analisis pada lintasan ini untuk nilai resistivitas 3 s.d. 26,7 $\Omega \mathrm{m}$ diduga sebagai lempung. Tanah permukaan memiliki nilai resistivitas 1,47 s.d. $55 \Omega \mathrm{m}$. Hasil klasifikasi lapisan bawah permukaan dapat diidentifikasi letak perlapisan bidang gelincir dari Gambar 7 hingga dapat dibuat gambar perlapisan batuan pada Gambar 8 sebagai berikut.

Hasil analisa dari lintasan ini, terdapat bidang gelincir yang cenderung searah dengan kemiringan lereng serta pada titik 0 $\mathrm{m}$ s.d. $100 \mathrm{~m}$ tanah permukaan diduga lebih tebal dan tidak ada lapisan penahan di bawahnya. Sehingga apabila terjadi peningkatan curah hujan tinggi, daerah ini dapat terjadi rawan longsor. Kondisi lintasan satu ini berada pada kemiringan $8^{\circ}$ s.d. $16^{\circ}$ dan berada di daerah pemukiman penduduk (Gambar 4). Demikian pada lintasan ini dapat dikatakan memiliki potensi rawan longsor.

\section{c. Lintasan Lima}

Berdasarkan Gambar 9, Lintasan 5 memiliki nilai resistivitas mulai dari 1.24$43,7<\Omega \mathrm{m}$. Analisis pada lintasan ini untuk nilai resistivitas 3,44-12,5 diduga sebagai lempung dan 15,6-43,7< $\Omega$ m sebagai breksi. Sedangkan tanah permukaan memiliki nilai resistivitas bervariasi, yaitu 1.24-43,7< $\Omega \mathrm{m}$. Dari hasil klasifikasi lapisan bawah permukaan dapat diidentifikasi letak perlapisan bidang gelincir dari gambar 4.30 hingga dapat dibuat gambar perlapisan batuan pada Gambar 10.

Penampang Gambar 10 menampakkan adanya perlapisan bidang gelincir pada kedalaman sepuluh meter dari permukaan. Akibat adanya bidang gelincir oleh perlapisan lempung maupun breksi pada 
Gambar 10, apabila terjadi curah hujan tinggi maka air akan merembes pada lapisan tanah permukaan, hingga tanah permukaan jenuh dan massa tanah bertambah akibat air, air selanjutnya menembus pada lapisan batuan lempung dan breksi. Lapisan batuan lempung dan breksi akan menjadi lunak dan licin, akibatnya lapisan lempung maupun breksi yang licin tidak mampu menahan tanah permukaan dengan massa yang telah bertambah, tanah permukaan yang jenuh akan jatuh menuruni lereng dan terjadilah tanah longsor.

\section{d. Interpretasi}

Secara keseluruhan pada penelitian ini tidak ditemukan singkapan batuan yang dapat digunakan untuk mengetahui hubungan nilai resistivitas dengan jenis batuan penyusun bawah permukaan. Lapisan bawah permukaan diidentifikasi berdasarkan referensi peta geologi lembar Yogyakarta pada Gambar 11 (Rahardjo, 1995). Daerah penelitian berada pada formasi Semilir dan Batuan Gunung Api tak Terpisahkan. Batuan penyusun formasi semilir adalah perselingan breksi-tuf, breksi batupaung, lava dan tuff serta batulempung tufan. Sedangkan batuan Gunung api tak terpisahkan terdiri dari tuf, abu, aglomerat, dan leleran lava tak terpisahkan, Selain keberadaan batuan yang ada pada formasi, pada daerah penelitan juga terdapat soil permukaan dimana soil ini merupakan hasil dari pelapukan batuan di sekitarnya (Toha, 1994). Berdasarkan sifat pada masing-masing batuan ini, tanah permukaan (soil) merupakan hasil batuan yang telah lapuk sehingga mudah menyerap zat cair dari luar. Tanah permukaan merupakan hasil pelapukan dari berbagai jenis batuan yang muncul dipermukaan, bisa jadi akibat suatu perpindahan maupun memang batuan lokal. Nilai resistivitas pada tanah permukaan bervariasi dari nilai terendah hingga tinggi. Pengelompokan jenis batuan dilakukan berdasarkan tabel re sistivitas batuan (Telford, 1990) serta kenampakan dan kesesuaian dilapangan.

Batuan lempung memiliki susunan mineral butiran yang halus dan kompak, apabila lapisan ini terkena zat cair akan cenderung menjadi lunak dan licin, hal ini menjadi peluang membentuk suatu bidang gelincir. Batuan Breksi merupakan batuan dengan mineral penyusun butiran runcing dan kasar sehingga sifatnya keras dan padat sehingga sulit ditembus oleh zat cair. Namun apabila zat cair menembus hingga lapisan batuan breksi, maka lapisan ini akan menjadi licin sedikit lunak dan pada lapisan ini dapat berpeluang terbentuk bidang gelincir. Hasil penelitian lapisan penyusun bawah permukaan seperti tampak pada Tabel 1.

\section{KESIMPULAN}

Adapun kesimpulan yang diperoleh adalah:

1. Hasil analisa lapisan bawah permukaan secara keseluruhan berdasarkan informasi geologi yang diperoleh, bahwa diduga penyusun lapisan bawah permukaan terdiri dari tanah permukaan, breksi dan lempung. Secara keseluruhan nilai resistivitas lempung diduga pada skala 0,01 s.d. $10 \Omega \mathrm{m}$, serta tanah permukaan (soil) pada 10 s.d. $55 \Omega \mathrm{m}$.

2. Hasil identifikasi lapisan bawah permukaan daerah rawan tanah longsor pada penelitian yang dilakukan pada enam lintasan, secara keseluruhan lima dari enam lintasan memiliki potensi tanah longsor. Hal ini karena dari lintasan-lintasan penelitian teridentifikasi adanya bidang gelincir yang terletak pada kemiringan yang cukup terjal. Bidang gelincir terbentuk dari perlapisan antara lapisan tanah permukaan dengan lempung dan atau breksi. Berdasarkan data peta kemiringan dan persebaran pemukiman penduduk maka lintasan 1 dan 2 berpotensi longsor. 


\section{UCAPAN TERIMAKASIH}

Ucapat terimahasih penulis berikan kepada mahasiswa UIN SUKA yang turut serta dalam pengambilan data untuk paper ini

\section{DAFTAR PUSTAKA}

Agustin, A. D., Utama W., dan Pandu G. N. R. 2017. Identifikasi Letak Cracks pada Bidang Longsor menggunakan Metode Resistivitas 2D, Jurnal Teknik ITS, 6 : 103 - 105.

BPBD Bantul. 2015. Data Tanah Longsor BPBD Kabupaten Bantu. Diakses pada tanggal 27 Maret 2018 pada https://bpbd.bantulkab.go.id/data/tan ah-longsor/kajian-tanah-longsor/.

Darsono, Nurlaksito B., dan Legowo B. 2012. Identifikasi Bidang Gelincir Pemicu Bencana Tanah Longsor Dengan Metode Resistivitas 2Dimensi di Desa Pablengan Kecamatan Matesih Kabupaten Karanganyar. Indonesian Journal of Applied Physics, 2 : 1 - 51.

Loke, M. H. 1999b. RES2DINV Rapid 2D Resistivity \& IP Inversion (Wenner, dipole-dipole, pole-pole, pole-dipole, Schlumberger, rectangular arrays) on Land, Underwater and Crossborehole Surveys; Software Manual Ver.3.3 for windows 3.1, 95 and NT, Penang, Malaysia.

Rahardjo, W., Sukandarrumidi dan Rosidi, H. M. D. 1995. Peta Geologi Lembar Yogyakarta, Jawa, skala $1: 100.000$, Pusat Penelitian dan Pengembangan Geologi, Bandung.

Telford, W. M., Geldart, L. P., dan Sheriff, R. E. 1990. Applied Geophysics 2nd $e d$, Cambridge Unai.
Toha, B., Resiwati, P., Rahardjo, W. dan Pramumidjojo, S. 1994. Geologi daerah Pegunungan Selatan suatu Kontribusi. Prosiding Geologi dan Geoteknik Pulau Jawa, Jurusan Teknik FT UGM, pp. 19-28.

Vernes. 1978. Slope Movement Types and Processes. In: Schuster RL, Krizek RJ (eds) Landslides, Analysis and Control, Special Report 176: Transportation Research Board, National Academy of Sciences, Washington DC, pp. 11.

Yatini, Y. and Suyanto, I. 2018. Identification of slip surface based on geoelectrical dipole-dipole in the landslides hazardous area of Gedangsari District, Gunungkidul Regency, Province of Daerah Istimewa Yogyakarta, Indonesia. IOP Conf. Ser.: Earth Environ. Sci. 212012013. 
Tabel 1. Nilai Resistivitas

\begin{tabular}{|c|c|c|}
\hline No & Lapisan Penyusun & $\begin{array}{c}\text { Skala Nilai Resistivitas } \\
(\Omega \mathrm{m})\end{array}$ \\
\hline 1 & $\begin{array}{c}\text { Tanah Permukaan } \\
(\text { soil) }\end{array}$ & $\begin{array}{c}1 \text { s.d. 55 (serta berada } \\
\text { dipermukaan sd kedalaman } \\
10 \mathrm{~m})\end{array}$ \\
\hline 2 & Batulempung & 0,001 s.d. 10 \\
\hline 3 & Breksi & $10-55$ \\
\hline
\end{tabular}

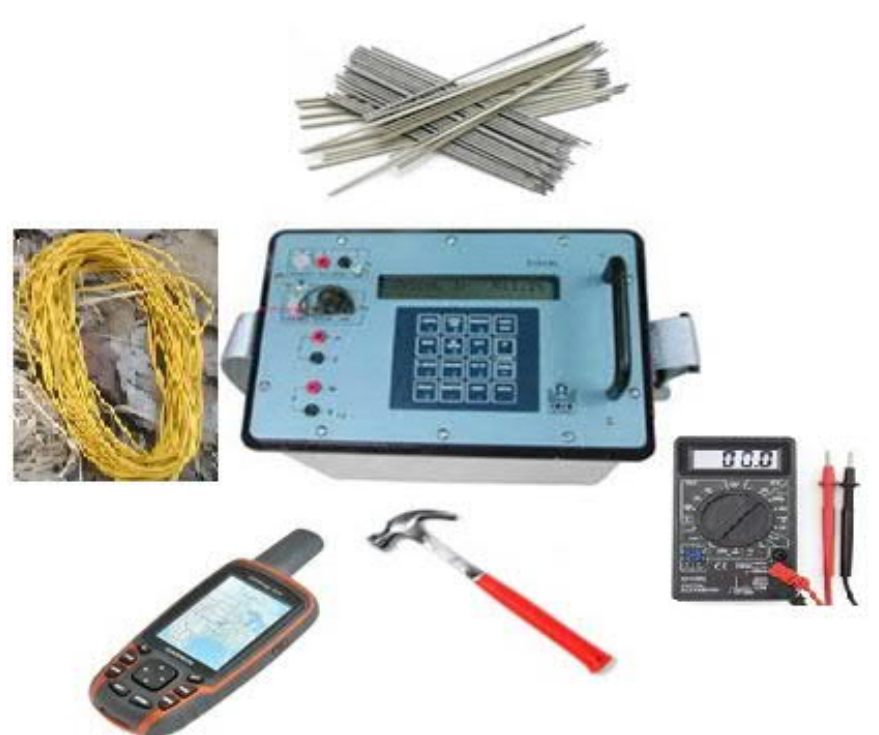

Gambar 1. Peralatan pengambilan data.

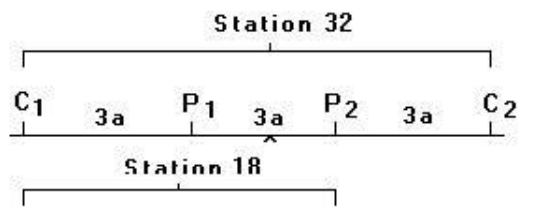

$$
\begin{aligned}
& \begin{array}{lllllll}
\mathrm{C}_{1} & & \mathrm{P}_{1} & \mathrm{P}_{1} & 2 \mathrm{a} & \mathrm{P}_{2} & \\
\hline
\end{array} \\
& \begin{array}{llll}
\text { Station } & 1 \\
\mathrm{C}_{1} & \mathrm{P}_{1} & \mathrm{P}_{2} & \mathrm{C}_{2}
\end{array}
\end{aligned}
$$$$
\text { Deta }
$$$$
\begin{array}{lllll}
1 & \mathrm{P}_{1} & \mathrm{P}_{2} & \mathrm{C}_{2} & \text { Electrode } \mathrm{Number}
\end{array}
$$

Resistivity Meter

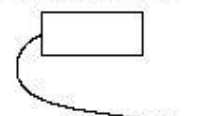

Multi-core cable

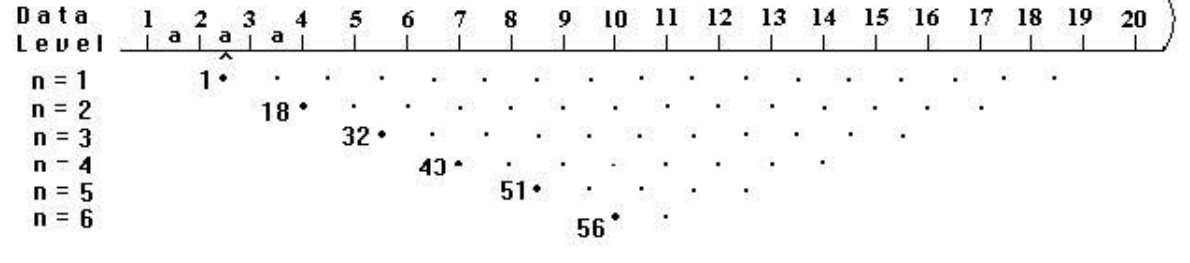

Sequence of measurements to build up a pseudosection

Gambar 2. Pengambilan data menggunakan Konfigurasi Wenner (Telford, 1990). 


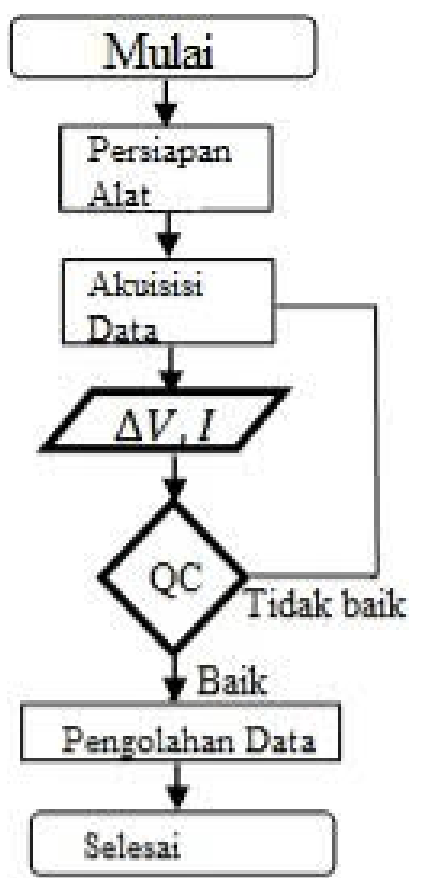

Gambar 3. Pengambilan data menggunakan Konfigurasi Wenner.

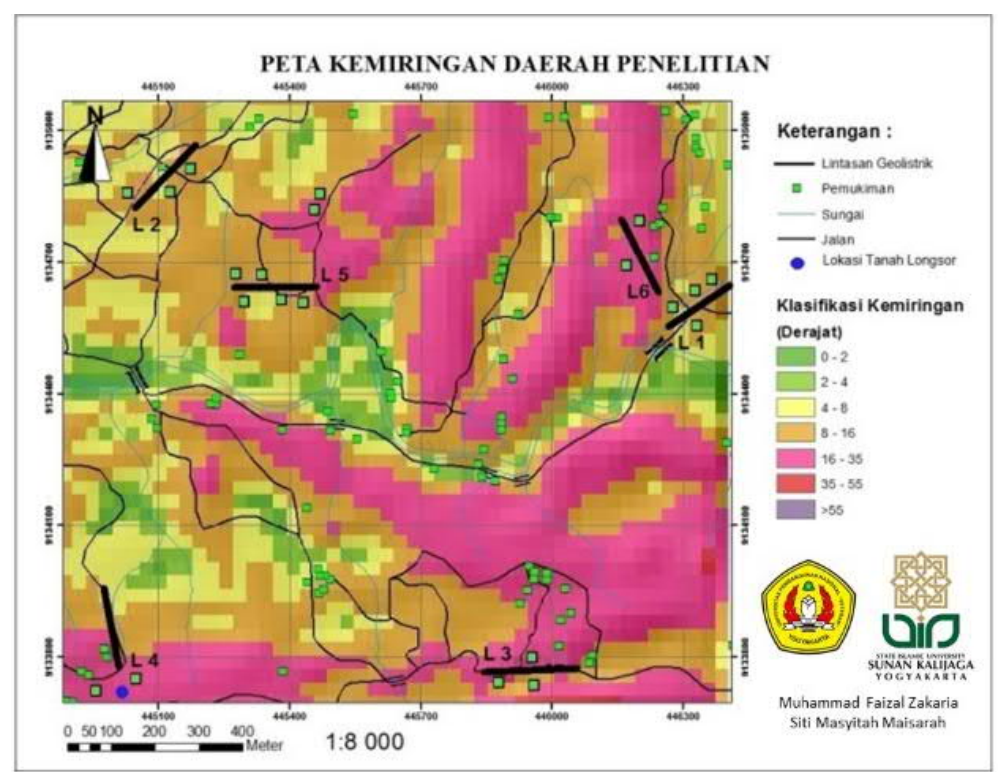

Gambar 4. Peta kemiringan daerah penelitian 


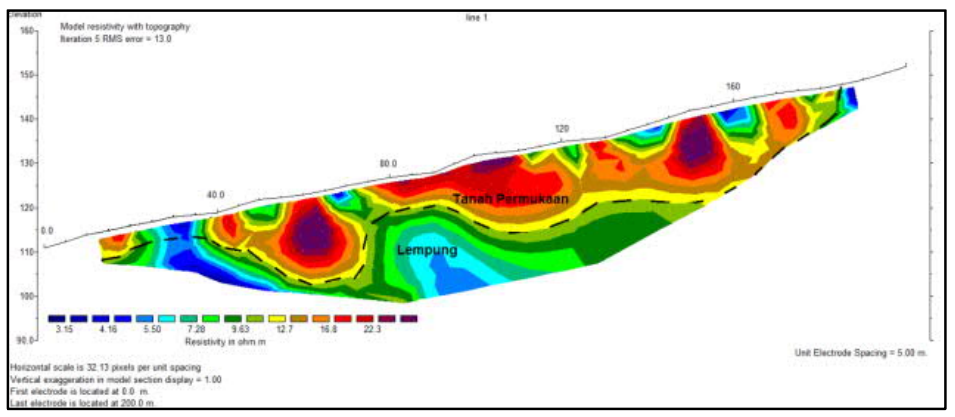

Gambar 5. Penampang litologi lintasan satu.

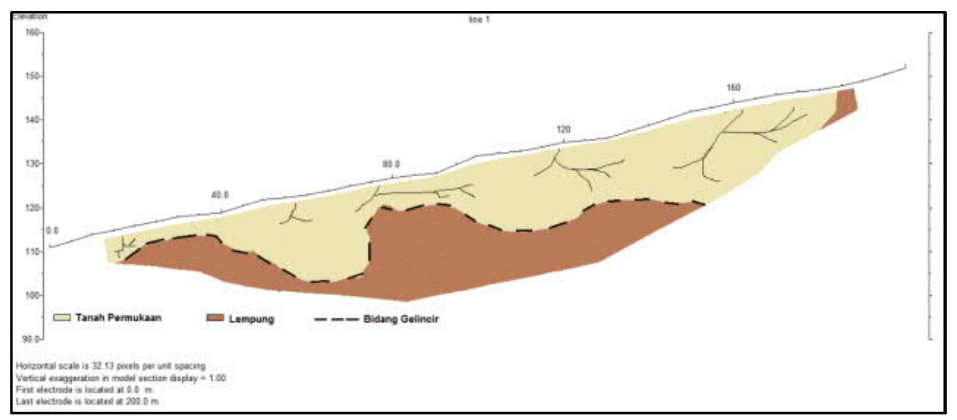

Gambar 6. Penampang letak bidang gelincir lintasan satu.

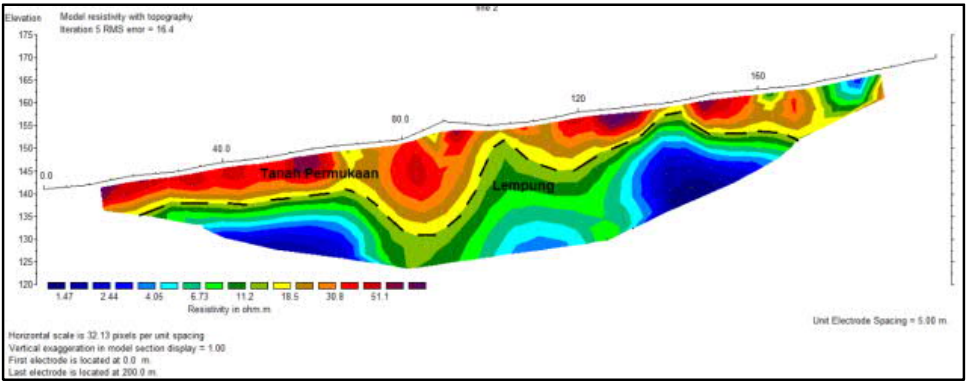

Gambar 7. Penampang litologi lintasan dua.

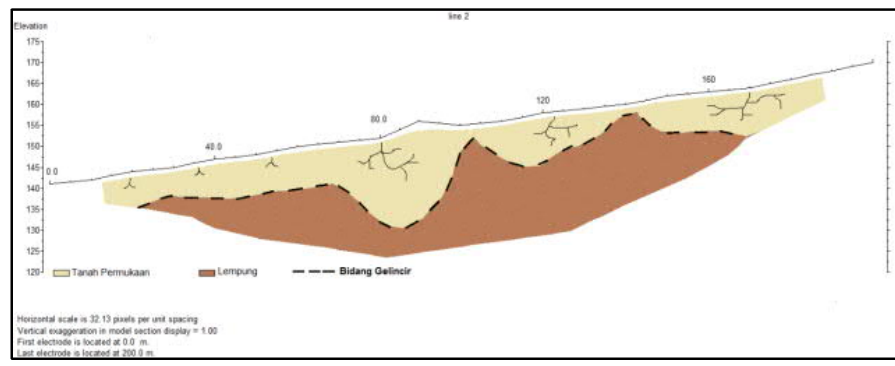

Gambar 8. Penampang letak bidang gelincir lintasan dua. 


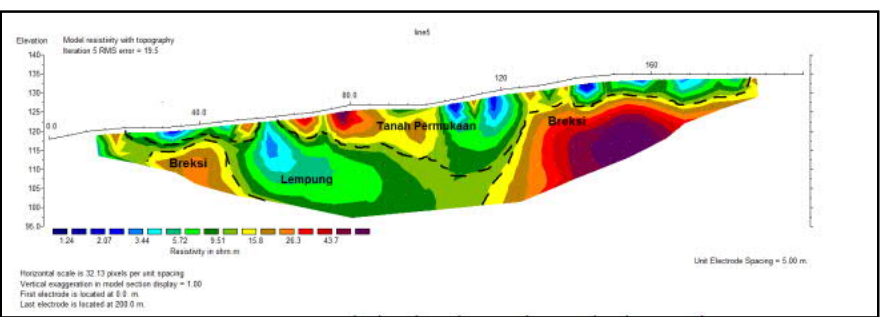

Gambar 9. Penampang litologi lintasan lima.

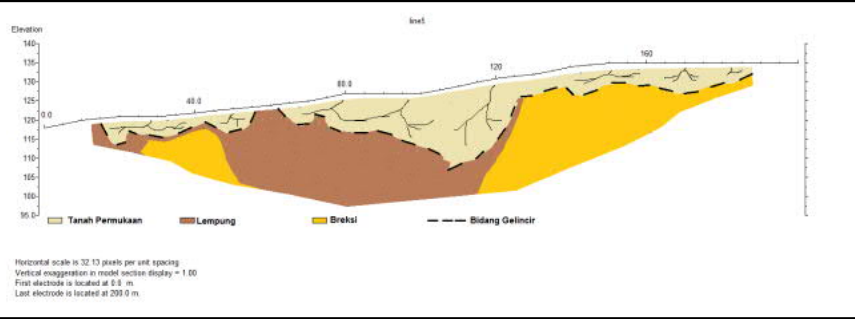

Gambar 10. Penampang letak bidang gelincir lintasan lima.

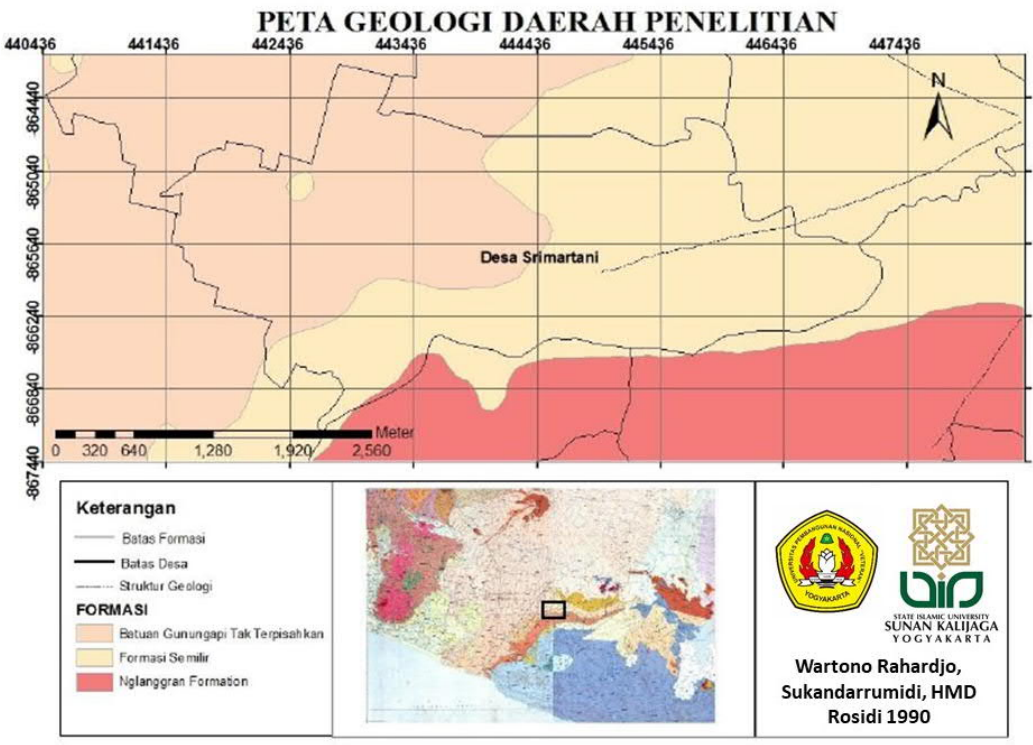

Gambar 11. Peta Geologi Lembar Yogyakarta (Rahardjo, 1990) 